\title{
Systematical Stream Offsets Resulting from Large Earthquakes Along the Strike-Slip Kunlun Fault, Northern Tibetan Plateau: Evidence from the $2001 M_{w} 7.8$ Kunlun Earthquake
}

\author{
Aiming Lin* \\ Graduate School of Science and Technology, Shizuoka University, Shizuoka 422-8529, Japan
}

\begin{abstract}
Field investigations and interpretations of high-resolution remote sensing images reveal geomorphic features of cumulative offsets and deflections of Holocene streams and gullies along the western 450-km segment of the Kunlun fault which triggered the $2001 \mathrm{M}_{\mathrm{w}} 7.8$ Kunlun earthquake in the northern Tibetan Plateau. The streams and gullies developed on Holocene alluvial fans are sinistrally displaced by up to $115 \mathrm{~m}$, with 3-5 m offsets caused by the 2001 Kunlun earthquake. Radiocarbon ages show that the alluvial fans formed in the past 6,000-9,000 years, suggesting an averaged slip rate of $16 \pm 3 \mathrm{~mm} / \mathrm{yr}$ over the past $6,000-9,000$ years on the western $450-\mathrm{km}$ segment of the Kunlun fault. Geomorphic and geologic evidence confirms that the systematical offsets of streams and gullies are the results of repeated large earthquakes and these topographic features are reliable indicators of seismic displacements accumulated on active strike-slip faults.
\end{abstract}

Keywords: Stream offset, slip rate, strike-slip Kunlun fault, $2001 \mathrm{M}_{\mathrm{w}} 7.8$ Kunlun earthquake, Tibetan Plateau.

\section{INTRODUCTION}

During the past two decades, the integration of geologic, geomorphic, seismic, and geophysical information has led to increased recognition and understanding of the tectonic significance of geomorphic features caused by strike-slip along active strike-slip faults (e.g., [1-5]). Tectonic landforms developed along active strike-slip faults are mainly characterized by systematic deflections and offsets of streams and terraces, and fault sags which are regarded as reliable displacement markers useful for reconstructing the long-term activity of active faults (e.g., [6-9]). It has been demonstrated that stream offsets and fault-bounded geologic structures such as pull-apart basins have resulted from repeated large strike-slip earthquakes (e.g., $[4,10])$. The study of tectonic geomorphology will provide a new insight into the seismic activity, longevity and structural evolution of active strike-slip faults.

The Kunlun fault is a typical continental strike-slip active fault, which triggered the $2001 \mathrm{M}_{\mathrm{w}} 7.8$ Kunlun earthquake in the northern Tibetan Plateau (Fig. 1) [8, 11,12]. This seismic event resulted in a $450-\mathrm{km}$-long surface rupture with up to $16.3 \mathrm{~m}$ of left-lateral displacement with along the western Kunlun fault $[8,11,13-15]$. It is the longest surface rupture zone with the largest co-seismic offset produced by a single intracontinental earthquake ever reported worldwide. After the earthquake, we have carried out a serious of studies on the geometric distribution patterns of co-seismic surface ruptures caused by the $2001 \mathrm{M}_{\mathrm{w}} 7.8$ Kunlun earthquake, paleoseismicity and Holocene average slip rate on the western-central eastern-segments of the Kunlun fault [8, 11, 13-18]. In this study, we use high resolution remote sensing

*Address correspondence to this author at the Institute of Geosciences, Faculty of Science, Shizuoka University, Shizuoka 422-8529, Japan; Tel/Fax: 81-54-238-4792; E-mail: slin@ipc.shizuoka.ac.jp images including $1 \mathrm{~m}$-resolution IKONOS and $0.61 \mathrm{~m}$-resolution QuickBird images and field investigations to examine systematic offset features of streams, gullies and terrace risers related to the 2001 co-seismic surface ruptures developed upon Holocene alluvial fans along the western segment of the Kunlun fault. These data are used to understand the seismic deformation characteristics and to reconstruct the long-term seismic activity of the strike-slip Kunlun fault.

\section{TECTONIC SETTING}

The Kunlun fault is located within the Kunlun mountains at an average elevation of $>4500 \mathrm{~m}$ in the northern Tibetan Plateau (Fig. 1). The Kunlun fault strikes E-W to WNW-ESE over $\sim 1200 \mathrm{~km}$ and is considered as one of the major strike-slip faults along which strike-slip partitioning occur in accommodating both the northeastward shortening and eastward extrusion of the Tibetan Plateau (e.g., $[19,20])$. The western segment of the fault, which triggered the $M_{w} 7.8$ Kunlun earthquake, cuts through south-sloping alluvial fans and bajadas, and is visible on satellite images as a straight lineament trending E-W to WNW-ESE (Fig. 1). The 2001 co-seismic surface rupture zone is restricted to this $\sim 450-\mathrm{km}$-long segment of the Kunlun fault with sinistral displacement of 2-16 m $[8,11,15]$. A Pleistocene average slip rate of $10-20 \mathrm{~mm} / \mathrm{yr}$ is estimated for this segment of the fault [21], and a uniform slip-rate of $11.5 \pm 2.0 \mathrm{~mm} / \mathrm{yr}$ has been proposed for the eastern $800 \mathrm{~km}$ segment of the Kunlun fault [22-24]. However, recent studies show that the slip rate is non-uniform and diminishes from an average slip rate of $\sim 16$ $\mathrm{mm} / \mathrm{yr}$ in the western segment [14] to $\sim 2 \mathrm{~mm} / \mathrm{yr}$ in the east end of the fault $[16,25]$ with an average gradient of $1 \mathrm{~mm} / 100 \mathrm{~km}$ along the strike-slip Kunlun fault [16].

More than 10 moderate-large earthquakes of $\mathrm{M}>6.0$ occurred on the Kunlun fault, which generally show a main focus mechanism of left-lateral strike-slip, but there are no 


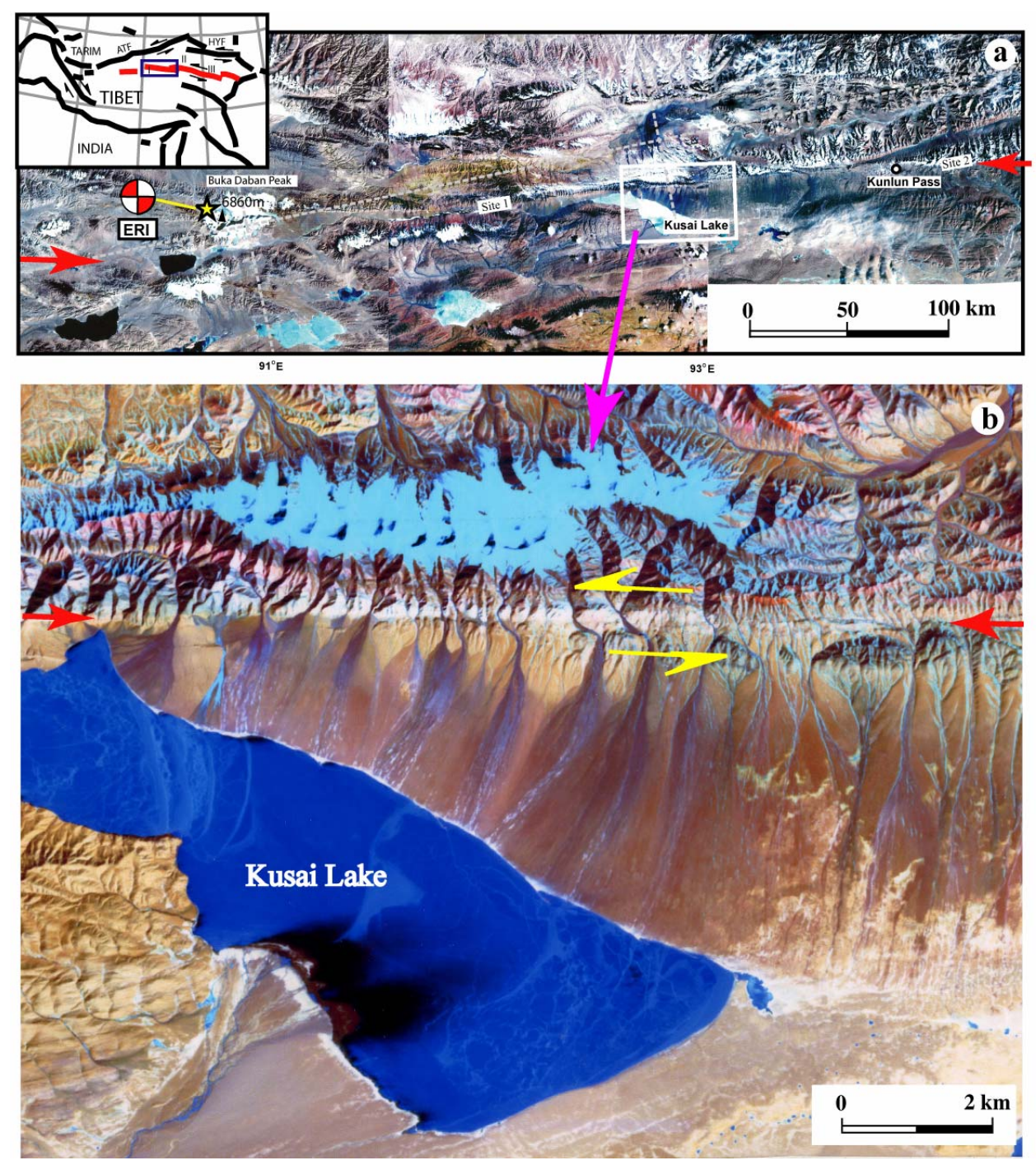

Fig. (1). (a) Landsat image showing the Kunlun fault (indicated by red arrows) in the study area. (b) Close-up view the Kunlun fault at the Kusai Lake area. Yellow arrows indicate the left-lateral shear sense of the Kunliun fault. I: An active splay fault of the Kunlun fault system that triggered the $1997 \mathrm{M}_{\mathrm{w}} 7.6$ Manyi earthquake. II: The western 400km segment related to the $2001 \mathrm{M}_{\mathrm{w}} 7.8$ Central Kunlun earthquake. III: The eastern $800 \mathrm{~km}$ segment of the Kunlun fault. KLF: Kunlun fault. HYF: Haiyuan fault. ATF: Altyn Tagh fault.

historical records of large earthquakes prior to the 2001 earthquake on the 450-km-long western segment of the Kunlun fault [15]. There are three large historic earthquakes of $M \geq 7.0$ prior to the $2001 \mathrm{M}_{\mathrm{w}} 7.8$ Kunlun earthquake occurred in the past century on the Kunlun fault, producing 40 $\mathrm{km}$ to $180 \mathrm{~km}$ long surface ruptures. One is the $1937 \mathrm{M} 7.5$ earthquake that ruptured the $150-180 \mathrm{~km}$ long Tuosuo Lake segment $[18,26]$. The second is the 1963 M 7.0 earthquake that produced a $40 \mathrm{~km}$ long surface rupture zone along the Alake Lake segment [17]. The third one is the 1997 Manyi $\mathrm{M}_{\mathrm{w}} 7.6$ earthquake that produced a $120 \mathrm{~km}$ long surface rupture zone [27]. Based on the trench and field investigations and interpretations of $1 \mathrm{~m}$-resolution IKONOS and $0.61 \mathrm{~m}$-resolution QuickBird images, a maximum strike-slip rate of $\sim 16 \mathrm{~mm} / \mathrm{yr}$ and an average recurrence interval of 300-400 years for large earthquakes have been estimated for the western segment associated with the $2001 \mathrm{M}_{\mathrm{w}} 7.8 \mathrm{Kun}-$ lun earthquake [14]. These historic earthquakes indicate that the Kunlun fault is currently active as a large earthquake source fault.

\section{GEOMORPHIC FEATURES OF CO-SEISMIC SUR- FACE DEFORMATION}

The co-seismic surface rupture extends from the east of Kunlun Pass past the northern side of Kusai Lake to the west of Bunka Daban Peak for $450 \mathrm{~km}$ (Fig. 1). The deformation characteristics and strike-slip offset distribution of the co-seismic surface rupture revealed by field investigations carried out immediately after the earthquake, seismic data, and satellite images have been described in a series of previous papers by our group $[8,11,13-17]$ and other groups [12, $28,29]$. The co-seismic surface ruptures are mainly composed of distinct shear faults, extensional cracks, and contractional structural such as mole tracks, which are generally concentrated in a surface deformation zone of 5-500 m along the pre-existing straight Kunluin fault trace $[8,11,13,15]$. The shear faults, a few meters to several hundred meters in an individual rupture strand length, sinistrally offset the south-sloping alluvial fans, terraces, glaciers, and moraines. The extensional cracks show a right-stepping en echelon pattern indicating a left-lateral shear sense and are oblique to 
the general trend of the fault trace. The mole-track structures are extensively observed along the surface rupture zone, which are developed within alluvial fans, river channels and bajada, and form a linked array of structures with the extensional cracks.

Tectonic landforms typical of strike-slip faults such as deflected or offset streams and ridges are well developed along the western segment of the Kunlun fault where the 2001 co-seismic ruptures overprint (Fig. 1). Landsat remote sensing images show that the south-flowing drainage system, south-sloping alluvial fans and terraces, and N-S-trending ridges are systematically deflected and offset in sinisitral along the Kunlun fault (Figs. 1b,2-4). Shutter ridges are well developed on the offset N-S-trending ridges. Alluvial fans bounded with the fault trace generally show an asymmetric shape and sinistral deflection pattern (Fig. 1b). The systematic offset of stream channels and gullies resulting from the 2001 earthquake are visible along the 450-km-long co-seismic rupture zone, which overprints the pre-existing Kunlun fault trace (Fig. 1b). We describe herewith two representative examples of the systematic offset of streams, gullies, and terrace risers observed at both the central (Site 1, around $\mathrm{E} 92^{\circ} 10^{\prime}, \mathrm{N} 35^{\circ} 5^{\prime}$ ') and eastern (Site 2, around $\left.\mathrm{E} 94^{\circ} 8^{\prime}, \mathrm{N} 35^{\circ} 39^{\prime}\right)$ end sites of the western segment of the Kunlun fault (see Fig. 1a for detail localities).

\section{Site 1}

Analysis of $1 \mathrm{~m}$-resolution IKONOS images reveals that more than ten south-flowing streams and gullies developed on south sloping alluvial fans have been sinistrally deflected or offset by up to $115 \mathrm{~m}$ along the Kunlun fault (Figs. $(\mathbf{2 , 3}$ ), Table 1). Sinistral offsets resulting from the 2001 earthquake range in 3-5 $\mathrm{m}$ around this site $[8,11]$, with larger gullies recording a greater offset (Figs. (2,3), Table 1). Higher terraces above the stream channels record larger offset of 25-32 $\mathrm{m}$ (T0 and T1 in Fig. 3), reflecting the cumulative nature of displacement along the fault.

Accumulated offsets of streams and terraces are also observed in the field (Fig. 4a-c). An outcrop of the fault zone was observed $1 \mathrm{~km}$ east of Site 1 , where the high terrace is offset by $\sim 25 \mathrm{~m}$, and the stream channel records $\sim 3.5 \mathrm{~m}$ offset produced by the 2001 Kunlun earthquake (Fig. 4a). Co-seismic surface ruptures are restricted to the pre-existing fault zone, where a $10-\mathrm{cm}$ thick fault gouge-breccia zone is developed (Fig. 4b). Horizontal striations developed on the fault plane indicate a sinistral strike-slip sense that is consistent with the earthquake focus mechanism (Fig. 4c). The terrace is mainly composed of unconsolidated sand and pebbles. One organic soil sample including charcoal was collected from the alluvial deposits at depth of $\sim 0.6 \mathrm{~m}$ from the top surface of the fan, which yielded an identical ${ }^{14} \mathrm{C}$ age of $8,730 \pm 40$ yr BP (C22, Table 2). This shows that this alluvial fan surface formed in the early Holocene.

\section{Site 2}

At Site 2, south-flowing streams and south-sloping alluvial fans are systematically offset by $60-115 \mathrm{~m}$ (Fig. 5a). The alluvial fans are generally asymmetric in shape and are curved to the east, consistent with sinistral offsets recorded at Site 1. This asymmetric shape of alluvial fans with an eastward curve is considered to be caused by the left-lateral slip along the fault. 4-5 m sinistral offsets of stream channels, gullies and terraces caused by the 2001 Kunlun earthquake are observed in both the field [14] and IKONOS images (Fig. 5b).

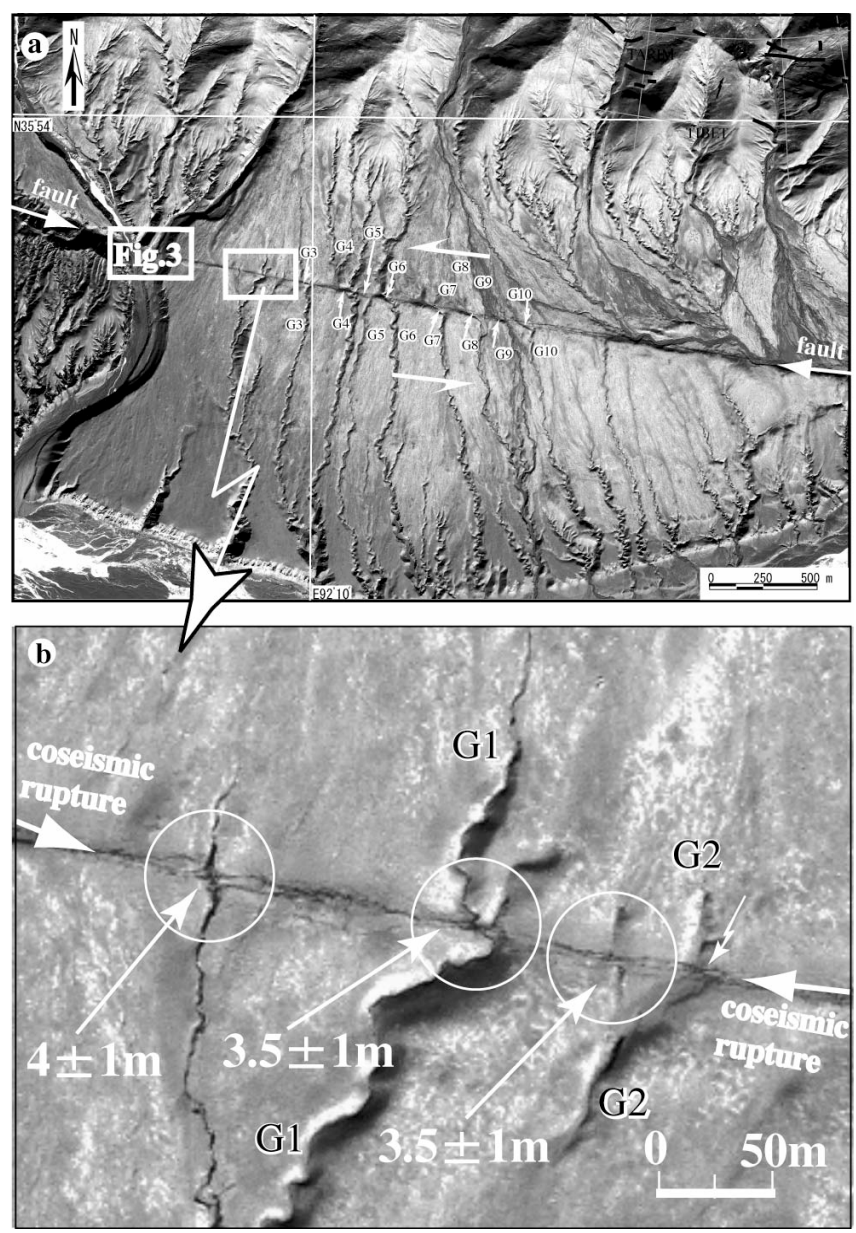

Fig. (2). (a) 1m-resolution IKONOS image showing systematic of offset streams and terraces developed on alluvial fans at Site 1. (b) Close-up view of (a) showing co-seismic offset caused by the 2001 Ms earthquake. Numbers G1-G10 indicate offset streams or gullies. Displacements are indicated by long white arrows and open circles (b), and are listed in Table 1. The offsets of $3.5 \pm 1 \mathrm{~m}$ and $4 \pm 1 \mathrm{~m}$ (indicated by white circles) are produced by the $2001 \mathrm{M}_{\mathrm{w}} 7.8$ earthquake.

In order to date the formation age of alluvial fan at this site, we excavated a trench through the alluvial fans at a height of $\sim 10 \mathrm{~m}$ above the current stream bed and collected material suitable for radiocarbon dating (Fig. 6). At the top of the excavation trench there is a $30 \mathrm{~cm}$ layer of sand including some pebbles. The alluvial fan is mainly composed of unconsolidated gray-brown sand (unit 1) and pebbles with dark-gray organic soil lenses (unit 2) in the lower part of the trench (Fig. 6). Two organic soil samples including some flakes of charcoal samples taken from unit 2 were collected at depths of $0.9 \mathrm{~m}$ to $1.1 \mathrm{~m}$ (Fig. 6), which yielded identical ${ }^{14} \mathrm{C}$ ages of $6,116 \pm 63 \mathrm{yr} / \mathrm{BP}$ and $6,979 \pm 69 \mathrm{yr} \mathrm{BP}$, respectively, (Table 2). 

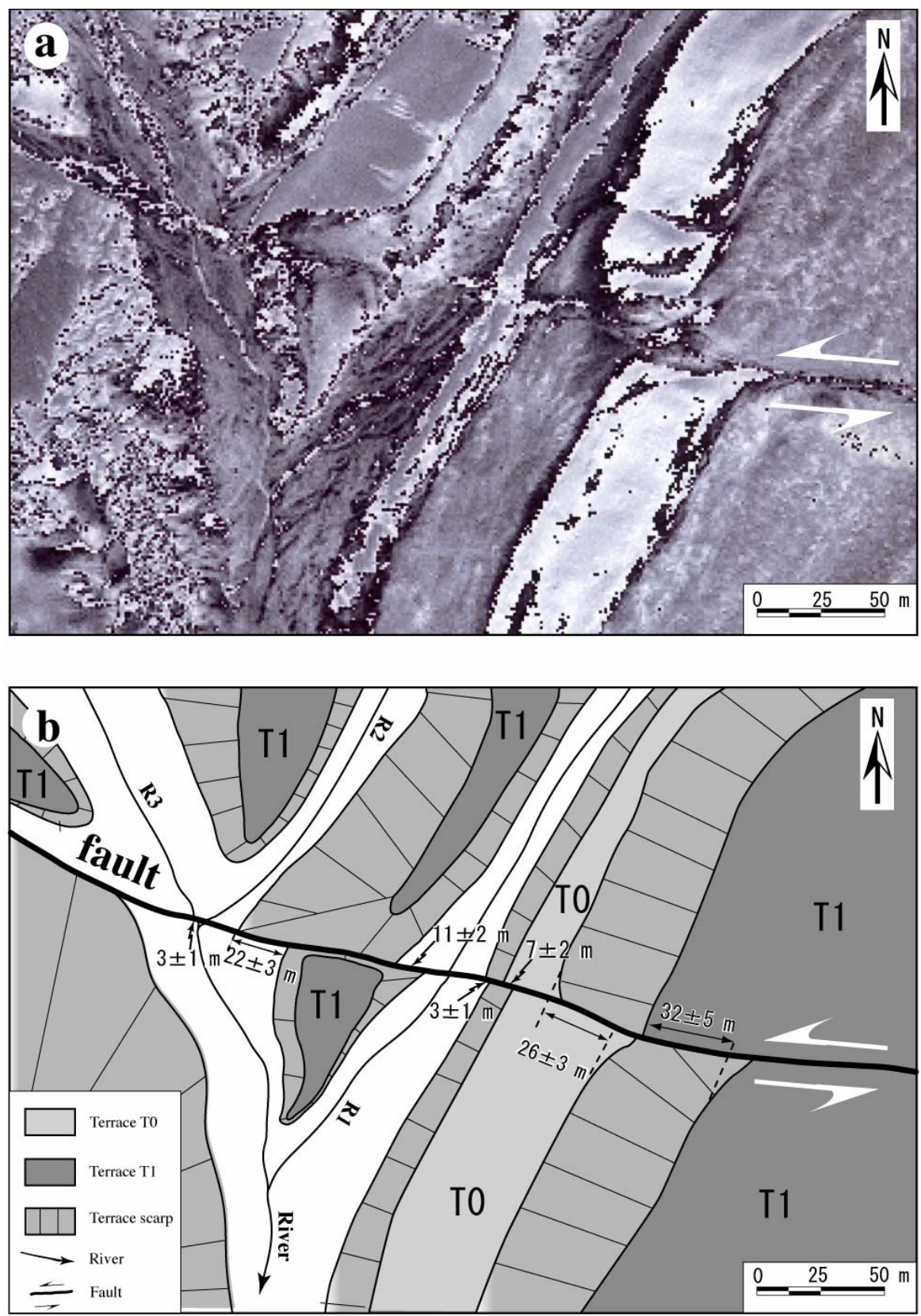

Fig. (3). (a) Close-up view of IKONOS image shown in Fig. (2a) and (b) corresponding sketch. Left-lateral offsets (11 $\pm 2 \mathrm{~m}, 7 \pm 2 \mathrm{~m}, 26 \pm 3 \mathrm{~m}$, $32 \pm 5 \mathrm{~m}$ ) are accumulated on the terraces. The offsets of $3 \pm 1 \mathrm{~m}$ at R1 and R3 are produced by the $2001 \mathrm{M}_{\mathrm{w}} 7.8 \mathrm{Kunlun}$ earthquake. T0 and T1: lower and higher terraces. R1-R3: Rivers.

\section{DISCUSSION}

While the displacement recorded by basement rocks may serve as a record of the long-term tectonic history of faults since the initiation of seismicity [4, 30-32], offset of small rivers and gullies developed on Holocene alluvial fans provides insight into the most recent deformation and seismicity of active faults (e.g., [4, 5, 9]). Large streams developed on mountain slopes adjacent to the Kunlun fault are offset by up to $1000 \mathrm{~m}$, and record $3-16.3 \mathrm{~m}$ sinistral displacement related to the $2001 \mathrm{M}_{\mathrm{w}} 7.8$ Kunlun earthquake [9]. As stated above, the offsets of the stream channels and gullies caused by the 2001 earthquake are only $3-5 \mathrm{~m}$ in the two study sites, whereas its related terrace risers, streams and gullies developed on the alluvial fans are offset by up to $32 \mathrm{~m}-115 \mathrm{~m}$.
Additionally, the slickenside striations generated on the co-seismic shear fault plane and the focus mechanisms of 2001 earthquake indicate a pure strike-slip shear sense. Co-seismic displacement resulting from an individual large earthquake is generally $<10 \mathrm{~m}$, and mature faults that record hundreds of kilometers of total offsets are considered to result from repeated seismic slips associated with many large earthquakes along the faults [9,33]. On the basis of the above observations, we conclude that the systematic offsets of up to $115 \mathrm{~m}$ of the streams developed inside the Holocene alluvial fans (Site 1) have been resulted from repeated sinistral strike-slip earthquakes along the Kunlun fault, and that the displaced topographic features are reliable indicators of co-seismic surface displacement along this active strike-slip fault. 

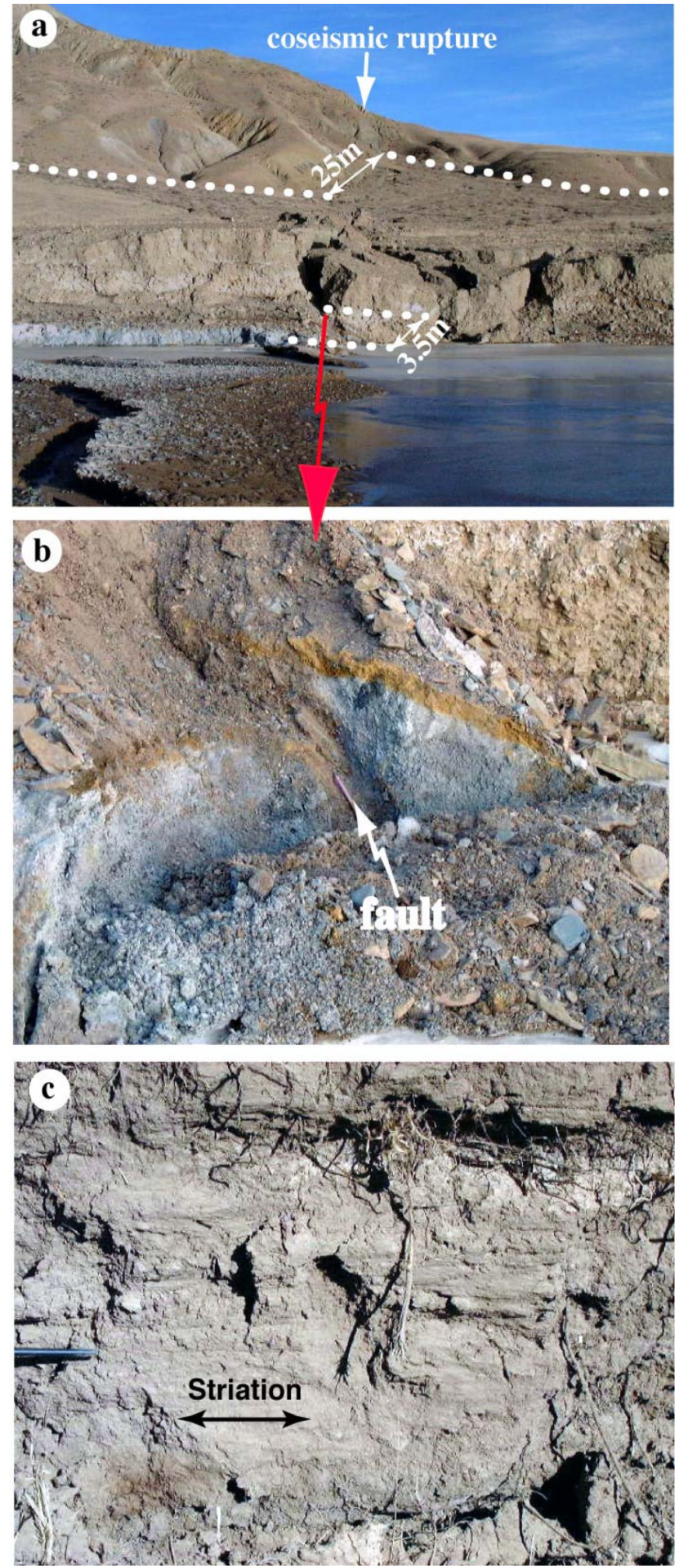

Fig. (4). Typical fault outcrop at Site 1 showing the 2001 co-seismic rupture overprinted on the pre-existing Kunlun fault. (a): The stream channel is offset $\sim 3.5 \mathrm{~m}$ by the 2001 earthquake, whereas a left-lateral offset of $25 \mathrm{~m}$ is accumulated on the high terrace. (b) Fault zone including $10 \mathrm{~cm}$ thick fault gouge-breccia zone along which the 2001 rupture occurred. (c) Horizontal slickenside striations developed on the fault plane indicate a left-lateral slip sense during the 2001 earthquake.
In order to estimate fault slip rate, we need to establish the ages of displaced topographic and geologic features such as terraces and alluvial fans and deposits along the Kunlun fault. Based on the relationships between the height of the terraces and fans from the streambeds and their abandonment ages, it is suggest that the incision rates of the streams developed in the late Pleistocene alluvial fans and terraces vary from 0.5 to $3 \mathrm{~mm} /$ year, with an average rate of $1 \mathrm{~mm} /$ year in the northern Tibetan Plateau $[9,34]$. Using this stream incision rate, we estimate the alluvial fans and terraces of heights of $<10 \mathrm{~m}$ in the study area formed in the past 5,000 $-10,000$ years. The ${ }^{14} \mathrm{C}$ ages show that the alluvial fans having a height of $<10 \mathrm{~m}$ developed in the two study sites formed in the past 6,000-9,000 years, which coincide with the previous dating results in the northern Tibet region. Based on the incision rate and the ${ }^{14} \mathrm{C}$ ages, the alluvial fans at both Site 1 and Site 2 with a height of $<10 \mathrm{~m}$ from the stream beds are inferred to have formed in the past 6,000-9,000 years. Coupled with the offset amounts of the streams and gullies and the ${ }^{14} \mathrm{C}$ ages, an averaged sinistral strike-slip rate of $16 \pm 3 \mathrm{~mm} / \mathrm{yr}$ is constrained for the western segment of the Kunlun fault over the past 6,000-9,000 years, which is consistent with that estimated from the trench investigations in the same segment of the Kunlun fault [14].

Li et al. [24] estimated an average slip rate of $10 \pm 1.5$ $\mathrm{mm} / \mathrm{yr}$ for the western segment of the Kunlun fault on the basis of TL (Thermoluminescence) dates of the alluvial deposits sampled from a few tens of centimeters below the terrace surfaces developed in Site 1 as described here. This slip rate is about one third less than that estimated in this study and Lin et al. [14]. What is the main reason caused this difference in the estimated slip rate? The offset amounts of main streams measured in Site 1 by Li et al. [24] and this study are quite similar, but dating methods of alluvial deposits are different. We dated the organic soils including some flakes of charcoals contained in the alluvial deposits using radiocarbon dating method in this study and Lin et al. [14]. Vegetation in the vicinity of the northern Tibetan Plateau is mainly composed of small grasses and lichens but no trees, which are therefore considered to be the source of the organic soil and flakes of charcoal materials. Thus, the dated ages of such organic soil and flakes of charcoal should represent the true formation ages of the sedimentary deposits. In contrast, Li et al. [24] used TL (Thermoluminescence) dating method to date the alluvial deposits that are mostly originated from glacial deposits transported from the upstream in the study area. Systematic errors are possible for TL dating method because (1) the exposure history of the surface is only poorly known, (2) the surface has undergone significant erosion during the interval of interest, and (3) invalid assumptions concerning the isotope production rates [36]. There are two main considerable uncertainties of the Thermoluminescence method for dating the glacial deposits in the study area. Firstly, it is possible that the glacial deposits formed in different periods were mixed and re-deposited in the same location. Secondly, the incomplete re-set of Thermoluminescence signals may be preserved in the fine-grained deposits due to repeated glacial transportations and sedimentations. These uncertainties make it difficult to use the Thermoluminescence ages of glacial deposits for determining the formation age of terrace and alluvial fan 

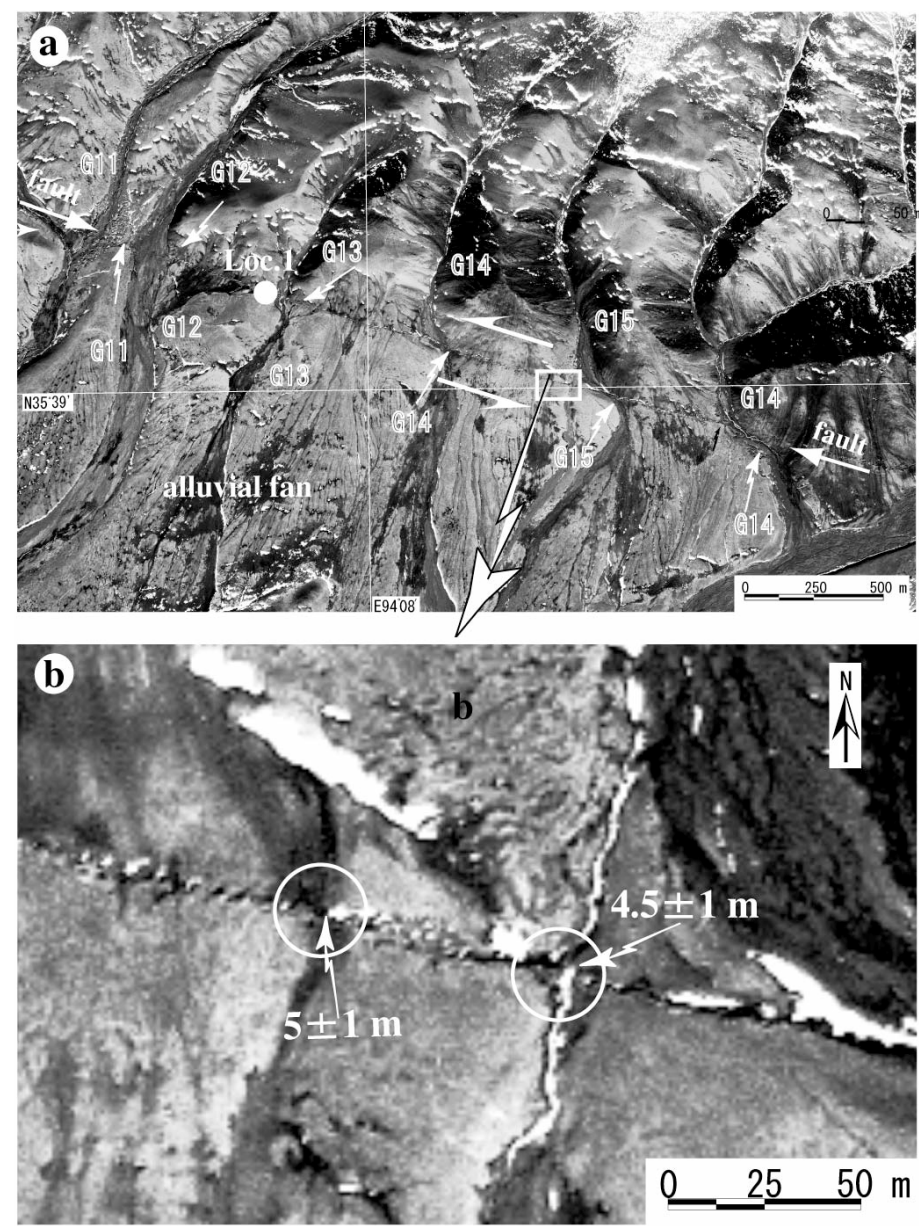

Fig. (5). (a) $1 \mathrm{~m}$-resolution IKONOS images showing systematic offset streams and terraces. (b) Co-seismic displacement resulting from the $2001 \mathrm{Ms} 8.1$ earthquake at Site 2. Numbers indicate the offset amounts. The offsets of $4.5 \pm 1 \mathrm{~m}$ and $5 \pm 1 \mathrm{~m}$ (indicated by white open circles) are produced by the $2001 \mathrm{M}_{\mathrm{w}} 7.8$ Kunlun earthquake. Numbers G11-G16 indicate offset streams. The offset amounts were measured in the locations indicated by white arrows, which are shown in Table 1. Location 1: Trench excavation location. Image data obtained after the earthquake on October 7, 2002.

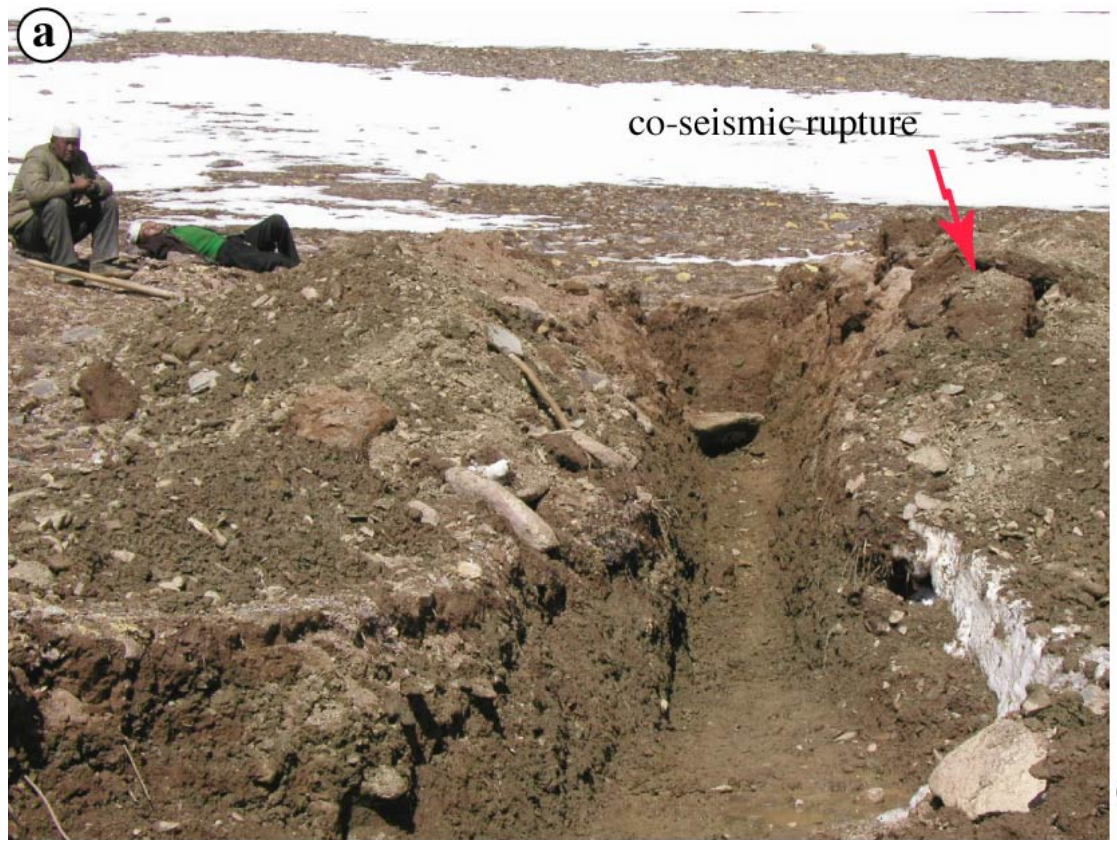

(b)

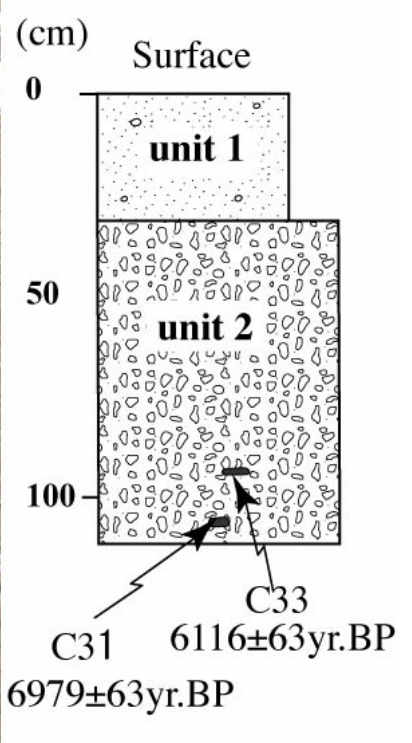

Fig. (6). (a) Photograph showing an all view of trench carried out on the alluvial fan at Site 2 and (b) descriptive log of the alluvial horizons. Calibrated calendar ${ }^{14} \mathrm{C}$ ages are shown in Table 2. 
Table 1. Cumulative Offsets of Streams and Gullies Measured at Site 1(G1-G10) and Site 2 (G11-G16), as Determined from $1 \mathrm{~m}$-Resolution IKONOS Images

\begin{tabular}{|c|c|c|c|c|c|c|c|c|c|c|c|c|c|c|c|c|}
\hline a Stre & G1 & 2 & 3 & 4 & 5 & G6 & G7 & 8 & G9 & 10 & 11 & 12 & $\mathrm{~s} 13$ & $\mathrm{~s} 14$ & G15 & G16 \\
\hline${ }^{\mathrm{b}}$ Offset(m) & \pm 3 & \pm & \pm & 10 & 1 & 9 & $60 \pm 7$ & $110 \pm 10$ & $57 \pm 8$ & $00 \pm 10$ & $115 \pm 20$ & $100 \pm 20$ & $65 \pm 10$ & $5 \pm 20$ & \pm 20 & $115 \pm 2$ \\
\hline
\end{tabular}

${ }^{a}$ Locations of streams (G1-G16) are indicated on Figs. $(\mathbf{4 , 6})$.

${ }^{\mathrm{b}}$ The offset amounts were measured using the method described by Maruyama and Lin [32], and errors reflect uncertainties in this method.

Table 2. Radiocarbon Dates from Sites 1 and 2

\begin{tabular}{|c|c|c|c|c|c|c|}
\hline Sample Code & ${ }^{\text {a }}$ Lab. ID & ${ }^{\mathbf{b}}$ Radiocarbon Age & 'Calendar Date & Location & Depth (cm) & Description \\
\hline \hline C-22 & 4544 & $8730 \pm 40 \mathrm{yr} \mathrm{BP}$ & $7941-7929$ BC & Site 1 & 60 & organic soil \\
\hline C-31 & 4533 & $6979 \pm 69 \mathrm{yr}$ BP & $5988-5725$ BC & Site 2 & 90 & organic soil \\
\hline C-33 & 4534 & $6116 \pm 63 \mathrm{yr} \mathrm{BP}$ & $5255-4813 \mathrm{BC}$ & Site 2 & 110 & organic soil \\
\hline
\end{tabular}

${ }^{a}$ Samples were analyzed at the Tono Geoscience Center, Japan Nuclear Cycle Development Institute.

${ }^{\mathrm{b}}$ Radiocarbon ages were measured by using AMS method.

${ }^{\mathrm{c}}$ Dendro-chronologically calibrated calendar age by the method and program of Stuvier et al. [35], with 2 standard deviation uncertainty.

surfaces. It is, therefore, difficult to evaluate the Thermoluminescence dating ages of the glacial deposits for estimating the slip rate of the Kunlun fault in the northern Tibetan Plateau.

\section{CONCLUSIONS}

Based on the detailed topographic analysis, interpretations of high-resolution remote sensing images, and field investigations given above, the following conclusions can be obtained:

1. Accumulative offsets and deflections of Holocene streams and gullies are developed along a 450-km-long western segment of the strike-slip Kunlun fault where 2001 co-seismic surface rupture zone overprints in the northern Tibetan Plateau.

2. The streams and gullies are developed on Holocene alluvial fans and are sinistrally displaced by up to 115 $\mathrm{m}$ at two study sites, with 3-5 $\mathrm{m}$ of offsets produced by the $2001 \mathrm{M}_{\mathrm{w}} 7.8$ Kunlun earthquake.

3. It is estimated that the averaged slip rate on the western $450-\mathrm{km}$-long segment of the Kunlun fault is $16 \pm 3$ $\mathrm{mm} / \mathrm{yr}$ over the past 9,000 years.

4. Geomorphic and geologic evidence confirms that the systematical sinistral offsets of streams and gullies are the result of repeated large earthquakes and these features are reliable indicators of seismic displacements along active strike-slip faults.

\section{ACKNOWLEDGEMENTS}

I would like to thank Drs. T. Maruyama, J. Guo and B. $\mathrm{Fu}$ (the graduate students of the Shizuoka University during this study) for assistance in the field. Thanks are also due to Prof. G. Dang for kind permission to use the field photographs. This work was supported by the Nuclear and Industrial Safety Agency, Japan and the Science Project (Project No. 18340158 for A. Lin) of the Ministry of Education, Culture, Sports, Science and Technology of Japan.

\section{REFERENCES}

[1] R. E. Wallace, Ed, "The San Andreas fault system, California", Prof Pap-Geol Surv. (U.S.), vol. 1515, 183p, 1990.

[2] J. Jackson, R. Norries, J. Youngson, "The structural evolution of active fault and fold systems in central Otago, New Zealand: evidence revealed by drainage patterns", J. Struct. Geol., vol.18, pp. 217-234, Feb 1996.

[3] A. Hubert-Farrari, R. Amijo, G. King, B. Meyer, A. Barka, "2002. Morphology, displacement, and slip rates along the North Anatonian Fault, Turkey", J. Geophys. Res., vol. 107, ETG 0-1-33 (doi.10.1029/2001 JB000393, 2002.

[4] T. Maruyama, A. Lin, "Late Quaternary faulting history of the strike-slip active faults inferred from offsets of topographic features and basement rocks: a case study of the Arima-Takatsuki Tectonic Line, southwest Japan", Tectonophysics, vol. 344, pp. 81-101, Jan 2002.

[5] T. Maruyama, A. Lin, "Slip sense inversion on active strike-slip faults in southwest Japan and its implications for Cenozoic tectonic evolution", Tectonophysics, vol. 383, pp. 45-70, April 2004.

[6] K. Sieh, R. H. John, "Holocene activity of the San Andreas fault at Wallace Creek, California", Geol. Soc. Am. Bull., vol. 95, pp. 883-896, Aug 1984.

[7] P. H. Leloup, R. Lacassin, P. Topponnier, et al."The Aliao Shan-Red River shear zone (Yunnan China), tertiary transform boundary of Indochina", Tectonophysics, vol. 251, pp. 3-84, Dec 1995.

[8] A. Lin, B. Fu, J. Guo, et al. "Co-seismic strike-slip and rupture length produced by the $2001 \mathrm{Ms} 8.1$ Central Kunlun earthquake", Science, vol. 296, pp. 2015-2017, June 2002.

[9] A. Lin, B. Fu, K. Kano, T. Maruyama, J Guo, "Late Quaternary right-lateral displacement along active faults in the Yanqi Basin, southern Tian Shan, northwest China", Tectonophysics, vol. 354, pp. 157-178, May 2002.

[10] R. Bilham, and G. C. P. King, "The morphology of strike-slip faults: examples from the San Andreas Fault, Coliforlia", J. Geophys. Res., vol. 94: pp.10,204-10,216, 1999.

[11] A. Lin, M. Kikuchi, B. Fu, "Rupture segmentation and process of the $2002 \mathrm{Mw} 7.8$ Central Kunlun earthquake, China", Bull. Seism. Soc. Am., vol. 93, pp. 2477-2492, Dec 2003.

[12] X. Xu, W. Chen, W. Ma, G. Yu, Y. Chen, "Surface ruptures of the Kunlunshan earthquake (Ms 8.1), northern Tibetan Plateau, China", Seism. Res. Lett., vol. 73, pp. 884-892, Nov 2002.

[13] A. Lin, J. Guo, B. Fu, "Co-seismic mole track structures produced by the 2001Ms 8.1 Central Kunlun earthquake, China", J. Struct. Geol., vol. 26, pp.1511-1519, Feb 2004

[14] A. Lin, J. Guo, B. Y. Awata, K. Kano, "Average slip rate and recurrence interval of large magnitude earthquakes on the western 
segment of the Kunlun fault, northern Tibet”, Bull. Seism. Soc. Am., vol. 96, pp.1597-1611, Oct. 2006.

[15] A. Lin, M. Nishikawa, "Coseismic lateral offsets of surface rupture zone produced by the $2001 \mathrm{Mw} 7.8$ Kunlun earthquake, Tibet from the IKONOS and QuickBird imagery", Int. J. Remote Sensing, vol. 27, pp. 2431-2445, DOI: 10.1080/01431160600647233, June 2007.

[16] A. Lin, J. Guo, "Millennial recurrence interval of large earthquakes on the eastern segment and non-uniform slip rate along the Kunkun fault, northern Tibet", Bull. Seism. Soc. Am., in press.

[17] J. Guo, A. Lin, T. Maruyama, J. Zheng, G. Sun, "New constraints on recent large earthquakes along the Xidatan-Dongdatan segment of the Kunlun fault, western China", Bull. Seism. Soc. Am., vol. 96, pp. 48-58, Feb 2006.

[18] J. Guo, A. Lin, G. Sun, J. Zheng, "The 1937 M7.5 earthquake and paleoseismicity along the Tuosuo lake segment of the Kunlun fault, northern Tibet, China", Bull. Seism. Soc. Am., vol. 97, pp. 474-496, April 2007.

[19] P. Molnar, B. C. Burchfiel, K. Liang, Z. Zhao, "Geomorphic evidence for active faulting in the Altyn Tagh and northern Tibet and qualitative estimates of its contribution to the convergence of India and Eurasia", Geology, vol. 15, pp. 249-253, March 1987.

[20] J. P. Avouac, P. Tapponnier, "Kinematic model of active deformation in central Asia. Geophys. Res. Lett., 20, 895-898, May1993.

[21] W. S. F. Kidd, P. Molnar, "Quaternary active faulting observed on the 1985 Academia Sinica-Rotal Society geotranvers of Tibet", Phil. Trans. London, vol. 327, pp. 337-363, Dec 1988.

[22] G. Zhao, "Quaternary faulting in North Qinghai-Tibet Plateau", Earthq. Res. China, vol.12, pp. 107-119, 1996 (in Chinese).

[23] J. Van der Woerd, P. Tapponnier, F. J. Ryerson, et al. "Uniform postglacial slip-rate along the central $600 \mathrm{~km}$ of the Kunlun Fault (Tibet), from ${ }^{26} \mathrm{Al},{ }^{10} \mathrm{Be}$, and ${ }^{14} \mathrm{C}$ dating of riser offsets, and climatic origin of the regional morphology", Geophys. J. Int., vol. 148, pp.356-388, Feb 2002.

[24] Li, H. J. Van der Woerd, P. Tapponnier, et al., "Slip rate on the Kunlun fault at Hongshui Gou, and recurrence time of great events comparable to the 14/11/2001, Mw 7.9 Kokoxili earthquake", Earth Planet. Sci. Let., vol. 237, pp. 285-299, May 2005.
[25] E. Kirby, N. Harkins, E. Wang, X. Shi, C. Fan, D. Burbank, "Slip rate gradients along the eastern Kunlun fault", Tectonics, vol.26, TC2010, doi:10.1029/2006TC002033, March 2007.

[26] Y. Jia, H. Dai, X. Su, "Tuosho Lake earthquake fault in Qinghai province", in: Research on Earthquake Faults in China, Xinjiang Seismological Bureau, Ed, Urumuqi, China, Xinjiang People Press, pp. 66-71 (in Chinese), 1988.

[27] X. Xu, "Seismic investigation on the Mani, northern Tibet earthquake", in: China Earthquake Yearbook, Seismological Press, Beijing, China, pp. 327-329, 2000 (in Chinese).

[28] China Seismological Bureau, "Album of the Kunlun Pass $M_{\mathrm{s}} 8.1$ earthquake”, Seismological Press, Beijing, China, pp.105, 2002 (in Chinese).

[29] Xu, X. G. Yu, Y. Klinger, P. Tapponnier, J. Van der Woerd, "Reevaluation of surface rupture parameters and faulting segmentation of the 2001 Kunlunshan earthquake (Mw7.8), northern Tibetan Plateau, China", J. Geophy. Res., vol. 111, doi:10.1029/20004JB003488, May 2006.

[30] R. Lacassin, A. Replumza, P. H. Leloup, "Hairpin river loops and slip-sense inversion on southeast Asian strike-slip faults", Geology, vol. 26, pp. 703-706, Aug. 1998.

[31] A. Lin, Z. Yang, Z. Sun, "When and how did the Yellow River develop its square bend", Geology, vol. 29, pp. 951-954, Oct 2001.

[32] T. Maruyama, A. Lin, "Tectonic history of the Rokko active fault zone (southwest Japan) as inferred from the accumulative offsets of stream channels and basement rocks", Tectonophysics, vol. 323, pp.197-216, April 2000.

[33] R. S. Yeats, K. Sieh, C. R. Allen, "The geology of earthquake", Oxford, UK, Oxford University Press, 557p, 1997.

[34] X. Feng, "The paleoearthquakes in Xinjiang region, China", Urumqi, China, Xinjiang Science \& Technology \& Hygiene Publishing House, 1997.

[35] M. Stuiver, P. J. Reimer, R. Reimer, "CALIB Radiocarbon Calibration Version 4.4, http://radiocarbon.pa.qub.ac.uk/calib/ (last accepted on Nov. 20, 2007), 2003.

[36] A. Lang, J. Moyab, J. Corominasb, L. Schrottc, R. Dikau, Classic and new dating methods for assessing the temporal occurrence of mass movements. Geomorphology, vol. 30, pp. 33-52, Oct 1999. 